\title{
More than two decades after the introduction of Limnoperna fortunei (Dunker 1857) in La Plata Basin
}

\author{
M. A. Pessotto ${ }^{a^{*}}$ and M. G. Nogueira ${ }^{a}$ \\ ${ }^{\text {a}}$ Departamento de Zoologia, Instituto de Biociências, Universidade Estadual Paulista - UNESP, Rua Prof. Dr. Antonio \\ Celso Wagner Zanin, s/n, CEP 18618-689, Botucatu, SP, Brazil \\ *e-mail: pessotto@ibb.unesp.br
}

Received: May 31, 2017 - Accepted: August 16, 2017 - Distributed: November 30, 2018

(With 5 figures)

\begin{abstract}
The golden mussel, Limnoperna fortunei, is an Asian freshwater bivalve introduced in South America in the beginning of the 1990's, probably through ballast water releases in La Plata River estuary. It dispersed north through Paraná, Uruguay and Paraguay Rivers. The study evaluated the macroscale $\left(18^{\circ}\right.$ to $34^{\circ} \mathrm{S} ; 45^{\circ}$ to $\left.60^{\circ} \mathrm{W}\right)$ distribution of $L$. fortunei (larval stages) in the main rivers and reservoirs of La Plata Basin. Samplings were performed through $68 \mu \mathrm{m}$ vertical plankton net hauls. Limnological variables were simultaneously determined. Larvae abundance correlated significantly with oxygen (positively) in summer, with temperature (positively) in winter and with total phosphorus and total nitrogen (both negatively) in winter. We expected densities to decrease towards north (latitudinal gradient) and increase in lentic conditions (reservoirs). Despite maximum density was found near the introduction point (La Plata River) similar value was also observed 2,000 km north (Paraguay River). The first hypothesis was refuted. The second hypothesis was partially accepted. Abundances were consistently higher in summer. Higher trophic conditions and fast flow seem to inhibit population growth. Food resources (chlorophyll a) locally influenced temporal variation. Limnoperna fortunei is widely distributed in La Plata basin, reaching high larval densities superior to 10,000 ind. $\mathrm{m}^{-3}$, in all major sub-basins. The species exhibits a high intrinsic dispersal ability (free planktonic larvae), wide tolerance to environmental factors and dispersion is potentialized by natural dispersion processes (e.g. fauna displacement) and human facilitation (e.g. commercial navigation).
\end{abstract}

Keywords: golden mussel, larval stage, Uruguay River, Paraguay River, Paraná River

\section{Duas décadas após a chegada de Limnoperna fortunei (Dunker 1857) na Bacia do Prata}

\section{Resumo}

O mexilhão dourado, Limnoperna fortunei, é um bivalve de água doce originário da Ásia e introduzido na América do Sul no início de 1990, provavelmente através da água de lastro liberada no estuário do rio La Plata. Dispersando-se para o norte através dos rios Paraná, Uruguai e Paraguai. Esse estudo avaliou a distribuição em macroescala $\left(18^{\circ}\right.$ a $34^{\circ} \mathrm{S} ; 45^{\circ}$ a $\left.60^{\circ} \mathrm{W}\right)$ de $L$. fortunei (estágios larvais) nos principais rios e reservatórios da bacia La Plata. Amostragens foram realizadas através de arrastos verticais com rede planctônica de $68 \mu \mathrm{m}$. Variáveis limnológicas foram simultaneamente determinadas. A abundância larval correlacionou-se significativamente com oxigênio (positivamente) no verão, com a temperatura (positivamente) no inverno e com fósforo total e nitrogênio total (ambos negativamente) no inverno. Esperávamos um decréscimo da densidade em direção ao norte (gradiente latitudinal) e aumento em condições lênticas (reservatórios). Apesar de a densidade máxima ter sido encontrada próximo do ponto de introdução (La Plata River) valores similares também foram observados $2.000 \mathrm{~km}$ ao norte (rio Paraguai). A primeira hipótese foi refutada. A segunda hipótese foi parcialmente aceita. Abundâncias foram consistentemente maiores no verão. Condições eutróficas e fluxo rápido parecem inibir o crescimento populacional. Recurso alimentar (clorofila a) local influenciou a variação temporal. Limnoperna fortunei está amplamente distribuído na bacia de La Plata, alcançando densidades larvais superiores a 10.000 ind. $\mathrm{m}^{-3} \mathrm{em}$ todas as principais sub bacias. A espécie possui alta capacidade de dispersão intrínseca (larva planctônica livre), ampla tolerância aos fatores ambientais e os processos de dispersão são potencializados por processos naturais (e.g. deslocamento de fauna) e facilitação humana (e.g. navegação comercial).

Palavras-chave: mexilhão-dourado, estágio larval, rio Uruguai, rio Paraguai, rio Paraná. 


\section{Introduction}

The effects of the progressive intensification the international commerce and human induced global changes promoted the increase of bioinvasion and inherent structural and functional impacts on natural environments (Lockwood et al., 2007; Darrigran and Damborenea, 2011).

Regarding to the unintentional invasions, a common example is the movement of species promoted by irresponsible discharges of ballast water (Carlton, 1985), which is believed to be responsible for the introduction of L. fortunei the golden mussel, in South America (Darrigran and Pastorino, 1995). The species, originated from rivers and streams of China and Southeast Asia (Morton, 1977), was identified for the first time in 1991 along the shores of La Plata River in Argentina (Pastorino et al., 1993).

Limnoperna fortunei is an r-selected species adapted to a wide range of aquatic environments, even brackish and marine waters (Morton, 1987). Important characteristics that make it a successful invader is the short life cycle, high fecundity, rapid growth and a wide physiological tolerance to several abiotic factors that often limit others aquatic invertebrates (Oliveira et al., 2011). The feeding plasticity is also an important feature assuring the species success (Rojas et al., 2015).

The species exhibits different reproductive strategies. In temperate zones from north hemisphere, there is a Unimodal pattern of reproduction, where larval production is limited to 1-2 summer months (Magara et al., 2001). However, in tropical and subtropical South America, larval releases can be more variable, from 6 up to 10 months along the year (Damborenea, 1999). According to (Darrigran, 2002), in the La Plata basin the temperature inferior threshold for the species reproduction is about $15-17^{\circ} \mathrm{C}$.

Recent studies on a meso scale distribution of $L$.fortunei in the high Paraná River basin shows that, in addition to food resources, some abiotic factors seem to facilitate the establishment of $L$. fortunei, such as oxygen content and water temperature (Ernandes-Silva et al., 2016).

The aim of this study is to provide a synoptic view of L. fortunei distribution in La Plata basin after two decades of its arrival in the continent. Analyzes are based on plankton larval stages. We expected a latitudinal south-north gradient, with higher abundance towards south where the species was introduced. Our second hypothesis is that more dense populations would be find in dammed river stretches (reservoirs) compared to free lotic sections (riverine stretches), as plankton organisms are better succeeded in lentic conditions. The possible influence of environmental variability on larval density was investigated through correlation analyses with limnological data simultaneously obtained.

\section{Methods}

\subsection{Study area}

The La Plata River basin is the second largest one in the continent, after the Amazonian. The area is $3.17 \times 106 \mathrm{~km}^{2}$, draining part of the territories of Argentina, Bolivia, Paraguay, Brazil, and Uruguay, with a mean flow of 22,000 $\mathrm{m}^{3} \mathrm{~s}^{-1}$ $\left(17,000 \mathrm{~m}^{3} \mathrm{~s}^{-1}\right.$ from Paraná/Paraguay Rivers and 5,000 $\mathrm{m}^{3} \mathrm{~s}^{-1}$ from Uruguay River) (Bazán and Arraga, 1993).

In the east-west direction the La Plata basin extends from the Atlantic Plateau or "Serra do Mar" (Southeast Brazil), to pre-Andean regions (South Bolivia/Northwest Argentina). The upper reaches is located in the Midwest region of Brazil, and the so-called La Plata River, a large fluvial-marine estuary, is the basin mouth into the Atlantic Ocean, between Uruguay and Argentina. Additional descriptions of the River Plate Basin can be found in (Pizarro et al., 1992; Tundisi, 1994; Boon et al., 2000 and Mugni et al., 2005).

The main rivers of La Plata basin are Paraná (Brazil, Paraguay and Argentina) - 4,695 km long and intensively dammed in the upstream stretch and tributaries; Uruguay (Brazil, Argentina and Uruguay) - 1,770 km, also with several hydropower reservoirs; and Paraguay (Brazil, Bolivia, Paraguay and Argentina) - 2,621 km without dams in the main course.

\subsection{Data collection and analysis}

In our sampling design it was considered free-flowing river stretches, mainly in the middle and lower regions of the basin as well as large reservoirs, mainly in the basin upper region (Figure 1).

Each considered reservoir was represented by two sampling points: one in the tail or upstream zone (sampling point name preceded by letter $U$ ) and the other in lentic or dam zone (sampling point name preceded by letter D).

The fieldwork was carried out in summer and winter periods. Most samplings, in 43 points each period (January/February and July), was performed in 2010 (project supported by FAPESP). In 2013 (July)/2014 (February) there was an opportunity to increase the samplings in a new project on transboundary rivers (supported by OEA), with additional samplings in 7 more points (but only 2 coincident to the previous ones).

In order to discriminate between summer and winter periods in data representations, before the sampling point name we added the letter S and W (as well the last two digits of the sampled year), respectively.

The location, name and respective geographic coordinates and altitude (GPS Garmin E-Trex) of the points are shown in Figure 1 and Table 1.

In the latitudinal axis (north $\rightarrow$ south), the maximum amplitude occurred between the points EMB-U (18 22' 33.09" S) and RPLA (34 $26^{\circ}$ ' 49.57' S). In the longitudinal direction (east $\rightarrow$ west), the highest variation was between FUR-U ( $45^{\circ} 31$ ' 24.18” O) and RPAR-L1 $\left(60^{\circ} 43^{\prime} 23.95\right.$ ' O). 


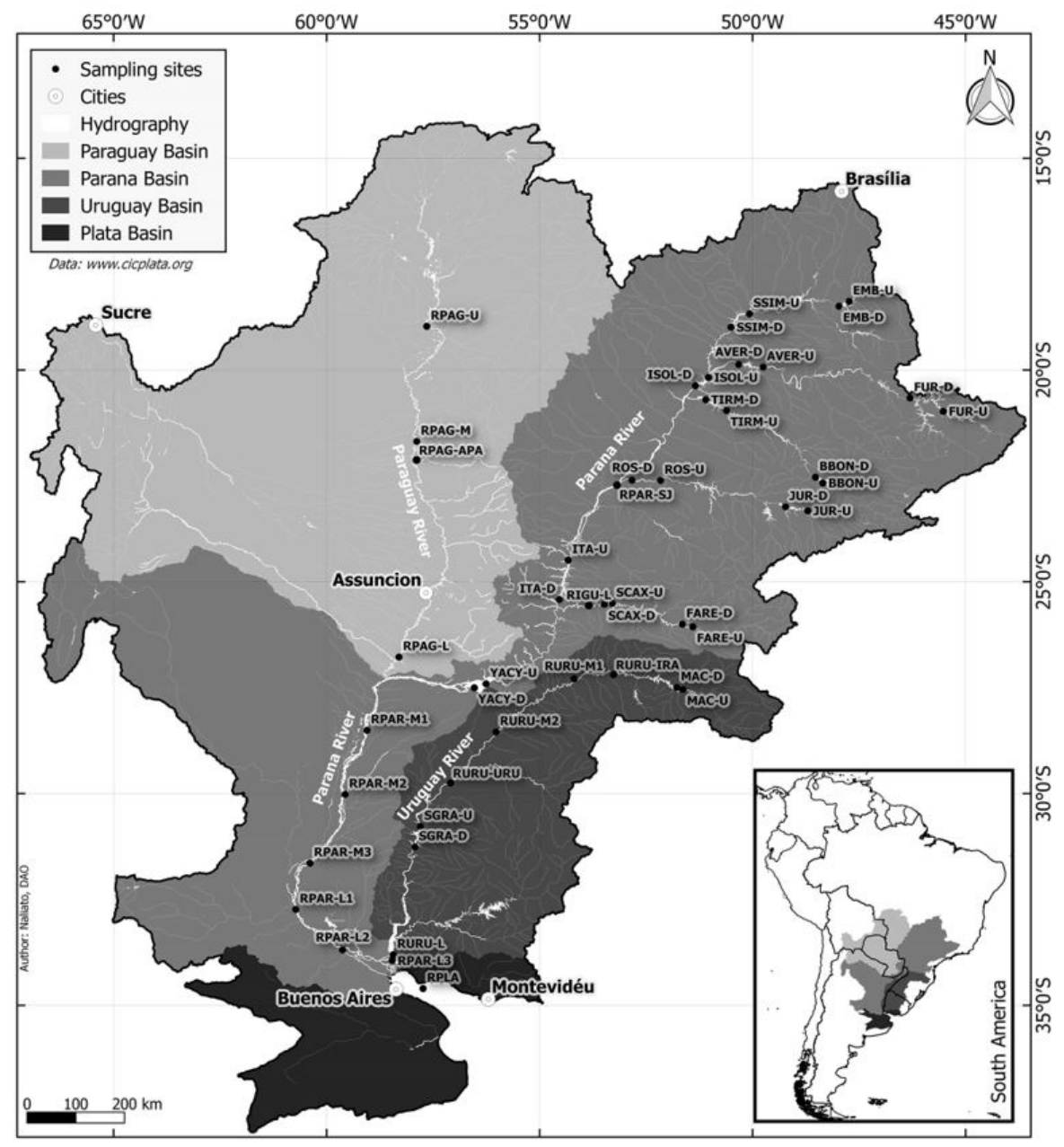

Figure 1. Sampling points distribution in the La Plata Basin. See Table 1 for denominations.

Table 1. List of sampling points with abbreviations, names and country (ARG/Argentina; BOL/Bolivia; BRA/Brazil; PAR/Paraguay; URU/Uruguay), locality (State/Province/Department/Municipality), geographical coordinates and altitude (Alt).

\begin{tabular}{|c|c|c|c|c|c|}
\hline $\mathbf{N}^{\circ}$ & Abbreviation & River/Reservoir (HPP) & Locality & Coordinates & Alt. (m) \\
\hline 1 & EMB-U & HPP Emborcação - BRA & Minas Gerais/Goiás & $18^{\circ} 22^{\prime} 40.47^{\prime \prime S} 47^{\circ} 44^{\prime} 3.58^{\prime \prime O}$ & 634 \\
\hline 2 & EMB-D & HPP Emborcação - BRA & Minas Gerais/Goiás & $18^{\circ} 29 ’ 33.09 ’ \mathrm{~S} 47^{\circ} 58^{\prime} 17.22^{\prime \prime O}$ & 648 \\
\hline 3 & SSIM-U & HPP São Simão - BRA & Minas Gerais/Goiás & $18^{\circ} 40^{\prime} 22.54^{\prime \prime S} 50^{\circ} 4 ’ 17.76^{\prime \prime O}$ & 402 \\
\hline 4 & SSIM-D & HPP São Simão - BRA & Minas Gerais/Goiás & 18॰59'15.59’'S 50³0'18.93”O & 406 \\
\hline 5 & FUR-U & HPP Furnas - BRA & Minas Gerais & $20^{\circ} 58^{\prime} 35.58^{\prime \prime} \mathrm{S} 45^{\circ} 31^{\prime} 24.18^{\prime \prime} \mathrm{O}$ & 771 \\
\hline 6 & FUR-D & HPP Furnas - BRA & Minas Gerais & $20^{\circ} 39^{\prime} 36.51$ '`S 46¹8'12.16”O & 769 \\
\hline 7 & AVER-U & HPP Água Vermelha - BRA & Minas Gerais/São Paulo & $19^{\circ} 55^{\prime} 42.17^{\prime \prime S} 49^{\circ} 45^{\prime} 5.31^{\prime \prime O}$ & 388 \\
\hline 8 & AVER-D & HPP Água Vermelha - BRA & Minas Gerais/São Paulo & 1952’03.73”S 50¹9'28.77”O & 388 \\
\hline 9 & BBON-U & HPP Barra Bonita - BRA & São Paulo & $22^{\circ} 40^{\prime} 04.08^{\prime \prime} \mathrm{S} 48^{\circ} 21^{\prime} 05.01^{\prime \prime} \mathrm{O}$ & 463 \\
\hline 10 & BBON-D & HPP Barra Bonita - BRA & São Paulo & $22^{\circ} 31^{\prime} 43.07^{\prime \prime} \mathrm{S} 48^{\circ} 31^{\prime} 26.05^{\prime \prime O}$ & 454 \\
\hline 11 & TIRM-U & HPP Três Irmãos - BRA & São Paulo & $20^{\circ} 57^{\prime} 21.57^{\prime \prime} \mathrm{S} 50^{\circ} 36^{\prime} 34.83$ ”O & 320 \\
\hline 12 & TIRM-D & HPP Três Irmãos - BRA & São Paulo & $20^{\circ} 41^{\prime} 57.09$ 'S $51^{\circ} 05^{\prime} 58.43^{\prime \prime O}$ & 326 \\
\hline 13 & JUR-U & HPP Jurumirim - BRA & São Paulo & $23^{\circ} 19^{\prime} 25.07^{\prime \prime} \mathrm{S} 48^{\circ} 42^{\prime} 11.07^{\prime \prime O}$ & 572 \\
\hline 14 & JUR-D & HPP Jurumirim - BRA & São Paulo & $23^{\circ} 13^{\prime} 41.07^{\prime \prime} \mathrm{S} 49^{\circ} 13^{\prime} 28.03^{\prime \prime O}$ & 566 \\
\hline 15 & ROS-U & HPP Rosana - BRA & São Paulo/Paraná & $22^{\circ} 36^{\prime} 28.27^{\prime \prime} \mathrm{S} 52^{\circ} 09^{\prime} 43.75^{\prime \prime O}$ & 262 \\
\hline 16 & ROS-D & HPP Rosana - BRA & São Paulo/Paraná & $22^{\circ} 36^{\prime} 04.71^{\prime \prime} \mathrm{S} 52^{\circ} 49^{\prime} 48.15^{\prime \prime O}$ & 261 \\
\hline 17 & FAR-U & HPP Foz do Areia - BRA & Paraná & $26^{\circ} 03^{\prime} 41.64^{\prime \prime} \mathrm{S} 51^{\circ} 24^{\prime} 02.25^{\prime \prime} \mathrm{O}$ & 754 \\
\hline
\end{tabular}

* Additional points sampled only in 2013/2014. ** Sampled in 2010, 2013 and 2014. 
Table 1. Continued...

\begin{tabular}{|c|c|c|c|c|c|}
\hline $\mathbf{N}^{\circ}$ & Abbreviation & River/Reservoir (HPP) & Locality & Coordinates & Alt. (m) \\
\hline 18 & FAR-D & HPP Foz do Areia - BRA & Paraná & 2559'57.06”S 51³8'52.27’O & 749 \\
\hline 19 & SCAX-U & HPP Salto Caxias - BRA & Paraná & $25^{\circ} 30^{\prime} 32.11^{\prime \prime S} 53^{\circ} 18^{\prime} 24.26 ” O$ & 333 \\
\hline 20 & SCAX-D & HPP Salto Caxias - BRA & Paraná & $25^{\circ} 31^{\prime} 50.96 ” S 53^{\circ} 28^{\prime} 45.76^{\prime \prime} \mathrm{O}$ & 319 \\
\hline $21 *$ & RIGU-L & Iguaçu River-BRA & Paraná & $25^{\circ} 35^{\prime} 33.87^{\prime} \mathrm{S} . . . . .53^{\circ} 53^{\prime} 23.99$ 'O & 280 \\
\hline 22 & ISOL-U & HPP Ilha Solteira - BRA & $\begin{array}{c}\text { São Paulo/Mato } \\
\text { Grosso do Sul }\end{array}$ & $20^{\circ} 10^{\prime} 29.60 ” S 51^{\circ} 2 ’ 7.06 ” O$ & 332 \\
\hline 23 & ISOL-D & HPP Ilha Solteira - BRA & $\begin{array}{c}\text { São Paulo/Mato } \\
\text { Grosso do Sul }\end{array}$ & $20^{\circ} 22^{\prime} 10.87^{\prime \prime S} 51^{\circ} 20 ’ 37.65^{\prime \prime O}$ & 321 \\
\hline $24 *$ & RPAR-SJ & $\begin{array}{l}\text { Paraná River - High } \\
\text { stretch - BRA }\end{array}$ & $\begin{array}{l}\text { Mato Grosso do } \\
\text { Sul/Paraná }\end{array}$ & $22^{\circ} 42^{\prime} 57.04^{\prime \prime} \mathrm{S} . . .53^{\circ} 10^{\prime} 58.33^{\prime} \mathrm{O}$ & 230 \\
\hline 25 & ITA-U & $\begin{array}{c}\text { HPP Itaipu - High stretch } \\
\text { - BRA/PAR }\end{array}$ & Paraná/ & $24^{\circ} 29^{\prime} 10.77^{\prime \prime S} 54^{\circ} 19^{\prime} 42.38^{\prime \prime O}$ & 217 \\
\hline 26 & ITA-D & $\begin{array}{c}\text { HPP Itaipu - High stretch } \\
\text { - BRA/PAR }\end{array}$ & Paraná/ & $25^{\circ} 25^{\prime} 09.67^{\prime \prime S} 54^{\circ} 32^{\prime} 14.47^{\prime \prime O}$ & 220 \\
\hline 27 & YACI-U & $\begin{array}{c}\text { HPP Yacyretá Middle } \\
\text { stretch - ARG/PAR }\end{array}$ & Corrientes/Itapúa & $27^{\circ} 24^{\prime} 24.13$ ”S 56¹5’19.86”O & 71 \\
\hline 28 & YACI-D & $\begin{array}{l}\text { HPP Yacyretá Middle } \\
\text { stretch - ARG/PAR }\end{array}$ & Corrientes/Itapúa & $27^{\circ} 30^{\prime} 9.12 ” S 56^{\circ} 31 ’ 56.69 ” O$ & 78 \\
\hline 29 & RPAR-M1 & $\begin{array}{c}\text { Paraná River - Middle } \\
\text { stretch - ARG }\end{array}$ & Corrientes/Santa Fé & $28^{\circ} 30^{\prime} 10.12^{\prime \prime S} 59^{\circ} 03$ '03.24”O & 43 \\
\hline 30 & RPAR-M2 & $\begin{array}{l}\text { Paraná River-Middle } \\
\text { stretch - ARG }\end{array}$ & Corrientes/Santa Fé & $30^{\circ} 01^{\prime} 07.73 ” \mathrm{~S} 59^{\circ} 33^{\prime} 50.86^{\prime \prime} \mathrm{O}$ & 26 \\
\hline 31 & RPAR-M3 & $\begin{array}{c}\text { Paraná River - Middle } \\
\text { stretch - ARG }\end{array}$ & Entre Rios/Santa Fé & $31^{\circ} 38^{\prime} 29.94^{\prime \prime S} 60^{\circ} 23 ’ 21.53$ ”O & 21 \\
\hline 32 & RPAR-L1 & $\begin{array}{c}\text { Paraná River - Low } \\
\text { stretch-ARG }\end{array}$ & Entre Rios/Santa Fé & $32^{\circ} 44^{\prime} 02.61^{\prime \prime S} 60^{\circ} 43^{\prime} 23.95^{\prime \prime O}$ & 5 \\
\hline 33 & RPAR-L2 & $\begin{array}{c}\text { Paraná River - Low } \\
\text { stretch - ARG }\end{array}$ & $\begin{array}{c}\text { Buenos Aires/Entre } \\
\text { Rios }\end{array}$ & $33^{\circ} 41^{\prime} 19.94$ ”S59³7’30.79”O & 5 \\
\hline 34 & RPAR-L3 & $\begin{array}{c}\text { Paraná River - Low } \\
\text { stretch - ARG }\end{array}$ & $\begin{array}{c}\text { Buenos } \\
\text { Aires/Entre Rios }\end{array}$ & $33^{\circ} 56^{\prime} 31.07^{\prime \prime S} 58^{\circ} 27^{\prime} 46.80^{\prime \prime O}$ & 5 \\
\hline 35 & RPLA & $\begin{array}{c}\text { La Plata River - URU/ } \\
\text { ARG }\end{array}$ & Colonia/Entre Ríos & $34^{\circ} 26^{\prime} 49.57^{\prime \prime S} 57^{\circ} 36^{\prime} 27.99^{\prime \prime O}$ & 1 \\
\hline 36 & RPAG-U & $\begin{array}{c}\text { Paraguay River - High } \\
\text { stretch - BOL/BRA }\end{array}$ & $\begin{array}{c}\text { Santa Cruz/Mato } \\
\text { Grosso do Sul }\end{array}$ & $18^{\circ} 58^{\prime} 07.73^{\prime \prime S} 57^{\circ} 38^{\prime} 55.75^{\prime \prime O}$ & 94 \\
\hline $37 * *$ & RPAG-M & $\begin{array}{c}\text { Paraguay River-Middle } \\
\text { stretch-PAR/BRA }\end{array}$ & $\begin{array}{c}\text { Alto Paraguay/ Mato } \\
\text { Grosso do Sul }\end{array}$ & $21^{\circ} 41^{\prime} 09.18^{\prime \prime S} 57^{\circ} 52^{\prime} 59.85^{\prime \prime O}$ & 71 \\
\hline $38 *$ & RPAG-APA & Apa River - PAR/BRA & $\begin{array}{l}\text { Concepción/Mato } \\
\text { Grosso do Sul }\end{array}$ & $22^{\circ} .4^{\prime} 59.22^{\prime \prime} \mathrm{S} . . . .57^{\circ} 56^{\prime} 30.18^{\prime \prime} \mathrm{O}$ & 80 \\
\hline 39 & RPAG-L & $\begin{array}{c}\text { Paraguay River - Low } \\
\text { stretch - ARG/PAR }\end{array}$ & $\begin{array}{l}\text { Resistencia/ } \\
\text { Ñeembucú }\end{array}$ & $26^{\circ} 51^{\prime} 15.42^{\prime \prime S} 58^{\circ} 19^{\prime} 21.45^{\prime \prime O}$ & 54 \\
\hline 40 & MAC-U & HPP Machadinho - BRA & $\begin{array}{l}\text { Santa Catarina/Rio } \\
\text { Grande do Sul }\end{array}$ & 27³2’26.71”S 51³7’52.31”O & 476 \\
\hline 41 & MAC-D & HPP Machadinho - BRA & $\begin{array}{l}\text { Santa Catarina/Rio } \\
\text { Grande do Sul }\end{array}$ & $27^{\circ} 29^{\prime} 27.77^{\prime \prime S} 51^{\circ} 46^{\prime} 26.50^{\prime \prime O}$ & 484 \\
\hline $42 *$ & RURU-IRA & $\begin{array}{l}\text { Uruguay River-High } \\
\text { stretch-BRA }\end{array}$ & $\begin{array}{l}\text { Iraí/Rio Grande do } \\
\text { Sul }\end{array}$ & $27^{\circ} 10^{\prime} 28.58^{\prime}{ }^{\prime} \mathrm{S} . . .53^{\circ} 13^{\prime} 39.44^{\prime \prime O}$ & 320 \\
\hline 43 & RURU-M1 & $\begin{array}{c}\text { Uruguay River - Middle } \\
\text { stretch - ARG/BRA }\end{array}$ & $\begin{array}{c}\text { Misiones/Rio Grande } \\
\text { do Sul }\end{array}$ & $27^{\circ} 17^{\prime} 15.23^{\prime \prime S} 54^{\circ} 11^{\prime} 31.66^{\prime \prime O}$ & 112 \\
\hline $44 * *$ & RURU-M2 & $\begin{array}{c}\text { Uruguay River - Middle } \\
\text { stretch - ARG/BRA }\end{array}$ & $\begin{array}{l}\text { Corrientes/Rio } \\
\text { Grande do Sul }\end{array}$ & $28^{\circ} 32^{\prime} 38.40^{\prime \prime S} 56^{\circ} 1$ '24.69”O & 54 \\
\hline $45^{*}$ & $\begin{array}{l}\text { RURU- } \\
\text { URU }\end{array}$ & $\begin{array}{c}\text { Uruguay River - Middle } \\
\text { stretch - ARG/BRA }\end{array}$ & $\begin{array}{c}\text { Passos de los Libres/ } \\
\text { Rio Grande do Sul }\end{array}$ & $29^{\circ} 44^{\prime} 48.91^{\prime \prime S} 57^{\circ} .5^{\prime} 43.20^{\prime \prime O}$ & 42 \\
\hline
\end{tabular}

* Additional points sampled only in 2013/2014. ** Sampled in 2010, 2013 and 2014. 
Table 1. Continued...

\begin{tabular}{|c|c|c|c|c|c|}
\hline $\mathbf{N}^{\circ}$ & Abbreviation & River/Reservoir (HPP) & Locality & Coordinates & Alt. (m) \\
\hline 46 & SGRA-U & $\begin{array}{l}\text { HPP Salto Grande - } \\
\text { URU/ARG }\end{array}$ & Salto/Entre Ríos & $30^{\circ} 46^{\prime} 27.52^{\prime \prime S} 57^{\circ} 47^{\prime} 55.53^{\prime \prime} \mathrm{O}$ & 33 \\
\hline 47 & SGRA-D & $\begin{array}{c}\text { HPP Salto Grande - } \\
\text { URU/ARG }\end{array}$ & Salto/Entre Ríos & $31^{\circ} 15^{\prime} 31.41^{\prime \prime S} 57^{\circ} 55^{\prime} 33.66^{\prime \prime O}$ & 34 \\
\hline 48 & RURU-L & $\begin{array}{l}\text { Uruguay River - Low } \\
\text { stretch - URU/ARG }\end{array}$ & Colonia/Buenos Aires & $33^{\circ} 48^{\prime} 07.39^{\prime \prime S} 58^{\circ} 26^{\prime} 07.48^{\prime \prime} \mathrm{O}$ & 8 \\
\hline
\end{tabular}

Plankton samples for $L$. fortunei larvae analysis were obtained through vertical hauls integrating the water column from near bottom (ca. $1 \mathrm{~m}$ ) to the surface. It was used a conical plankton net of $68 \mu \mathrm{m}$ of mesh size aperture. The net displacement was restricted to the first $40 \mathrm{~m}$, in rare cases of higher depths. Three identical samples were collected and analyzed in each point and fixed in $4 \%$ formaldehyde.

The effectiveness of the applied methodology for samplings collection and counting is supported by previous studies. Previous studies in the region, for both riverine and reservoir systems, demonstrated that $L$. fortunei distribution do not exhibits important differences along distinct depths of the water column (Brugnoli et al., 2011; Boltovskoy et al., 2015). Santos et al. (2005), from observations performed in Rio Grande do Sul State, reported that the minimum size of larvae is around $80 \mu \mathrm{m}$. (Eilers et al., 2011), through a discriminant analysis considering the proportion of different larval stage in samples collected in the Paraguay River, found that the stage " $\mathrm{D}$ " prevailed in $80 \%$ of the plankton larvae.

Vertical profiles of water temperature, dissolved oxygen concentration (DO), electrical conductivity, $\mathrm{pH}$ and turbidity were measured (every $1 \mathrm{~m}$ depth) in situ with a water quality probe daily calibrated (Horiba U-52). Water samples from surface, middle and bottom of the water column were taken with a Van Dorn bottle for chlorophyll a (total) analyzes (Golterman et al., 1978); total nitrogen (Strickland and Parsons, 1960) and total phosphorus (Mackreth et al., 1978), after simultaneous sampling digestion (Valderama, 1981) and total suspended solids (TSS), inorganic (IM) and organic matter (OM) fractions (APHA, 2005). It was also measured the Secchi disc transparency and the local depth using a SpeeedTech sonar.

Plankton samples were analyzed under stereomicroscope Zeiss Stemi SV6 at magnification of 100X. An aliquot of $1 \mathrm{ml}$ from the homogenized sample was placed in a Sedgewick-Rafter chamber for $L$. fortunei counting (type "D" larvae, veliger and umbonada). The procedure was repeated until the enumeration of at least 100 individuals. In case of low density at least $10 \%$ of the total sample volume was examined. Densities were expressed in individuals per cubic meter.

The average density value from the three samples simultaneously obtained was used for representing each sampling point/period.
For detection of spatial trends in the L. fortunei distribution a NMDS (Non - Metric Multidimensional Scaling) analysis (Primer 6 software) was performed. It was used the average values of larval densities for each considered sub-basin (Upper, Middle and Lower Paraná, Paraguay River, Iguaçu River, Uruguay and La Plata River).

An explorative analysis (correlation) was used for evaluation of the environmental factors affecting the larvae abundance of L. fortunei. Spearman correlation (Sigmaplot 11.0) was used, as data did not exhibit normal distribution. Variables measured along vertical profile were averaged and all values, including larval densities, were previously log transformed. Sampling points where larvae were not found were excluded from the analysis. Winter and summer data were considered separately.

\section{Results}

A wide variation in the larval density of $L$. fortune $i$ was found when considered the distinct sub-basins (Figure 2 and 3 ). Clearly higher abundances occurred during summer, except for only one sampling point of Iguaçu River (W10 SCAX-U) where a high value $\left(10,430\right.$ ind. $\left.\mathrm{m}^{-3}\right)$ was seen in winter. The maximum peak of $L$. fortunei larvae was observed in La Plata River estuary (60,000 ind. $\mathrm{m}^{-3}$, summer 2010) were the seasonal amplitude was extremely high as well (300 times difference; only 200 ind. $\mathrm{m}^{-3}$ in winter 2010).

Plankton larvae of L. fortunei were observed in practically all sampling points of the southern region of La Plata basin, including La Plata River, Low and Middle Paraná River and Low Uruguay River the larval. In addition to La Plata River, already mentioned, high densities were also found in Low Uruguay River (S10SGRA-D with 47,976 ind. $\mathrm{m}^{-3}$; S10 RURU L with 22,253 ind. $\mathrm{m}^{-3}$ ) and Middle Paraná River (S10YACY-D with 16,079 ind. $\mathrm{m}^{-3}$ ).

For the northern portion of the basin comprised by Paraguay River and the upper Paraná River, including its three main tributaries, Tietê, Paranapanema and Iguaçu, the distribution of larvae was more irregular, even with some points with no register (e.g. Rivers Paranaíba and Grande). For this region, higher densities $\left(>10,000\right.$ ind. $\left.\mathrm{m}^{-3}\right)$ occurred in Paraná River (S10ISOL U and S14RPARSJ) (ca. 11,000 ind. $\mathrm{m}^{-3}$ ), River Iguaçu (W10SCAXU) (ca. 10,000 ind. $\mathrm{m}^{-3}$ ) and River Paraguay (S10RPAGU 

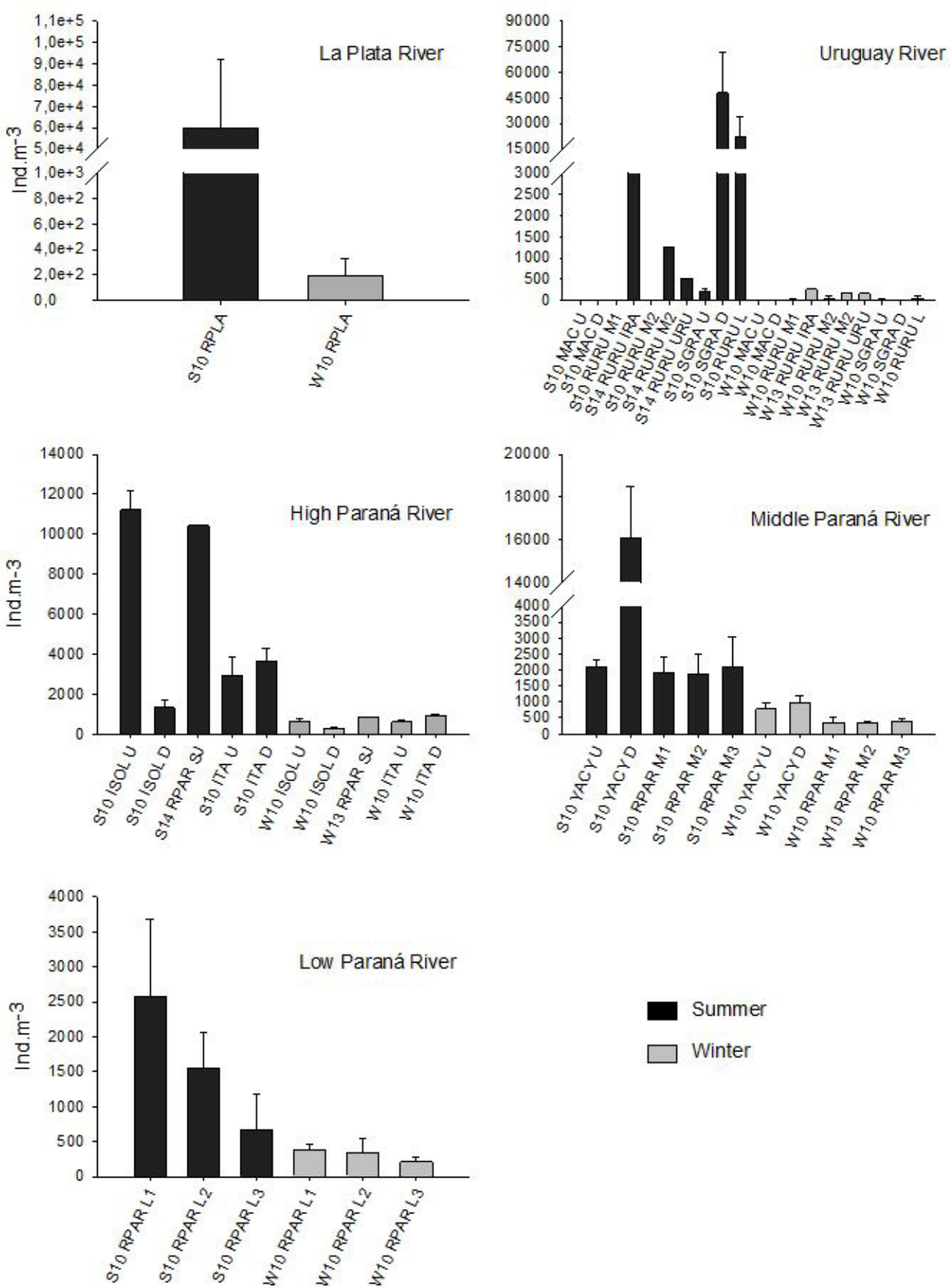

Summer

Winter

Figure 2. Variation of L. fortunei larval densities (mean values and standard deviation) in the main La Plata sub-basins during summer and winter. Notice differences in the scales.

and S10RPAGM) (ca. 52,000 and 20,000, respectively) (Figure 3).

In order to identify wide-ranging spatial patterns, average values of $L$. fortunei densities were calculated from the entire data set obtained for each major sub-basin (Figure 4). Higher values occurred in the La Plata River, followed by Paraguay River, while lower larvae abundance was associated with the Paraná River (low and high stretches). This distribution pattern is evidenced by the NMDS analysis (Figure 5).

Correlation between environmental variables (Table 2) and larvae abundances are shown in Table 3. Significant positive value was observed for dissolved oxygen (summer data) and temperature (winter data) and significant negative values were observed for total nitrogen, total phosphorus (both winter data). 

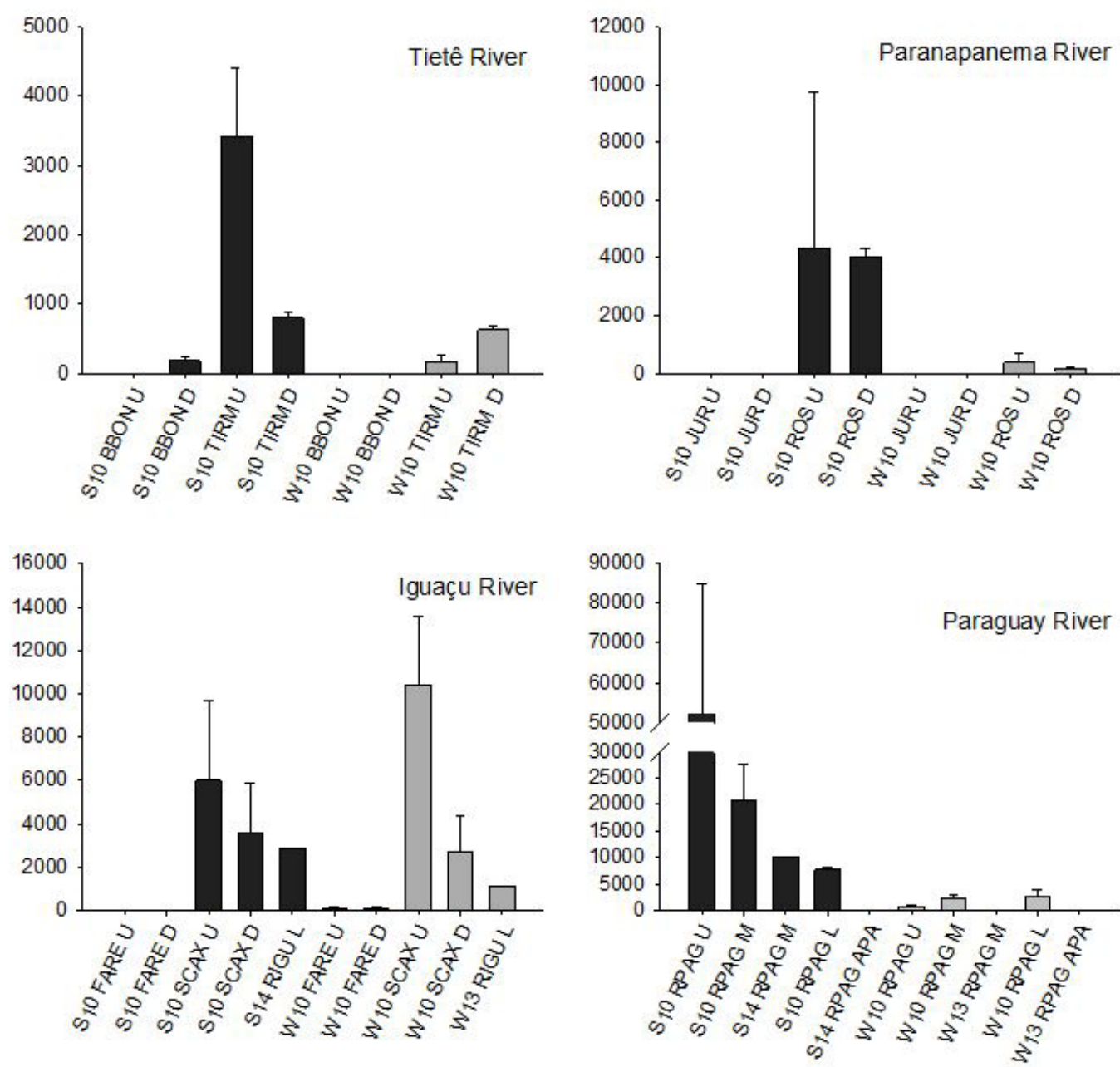

Summer

\section{Winter}

Figure 3. Continued. Variation of L. fortunei larval densities (mean values and standard deviation) in the main La Plata sub-basins during summer and winter. Notice differences in the scales.

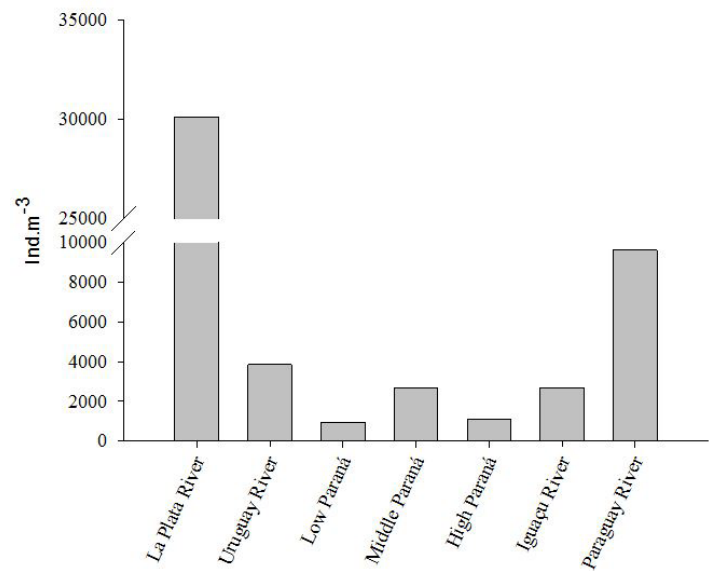

Figure 4. Variation of L. fortunei larval densities (mean values) in the main La Plata sub-basins.

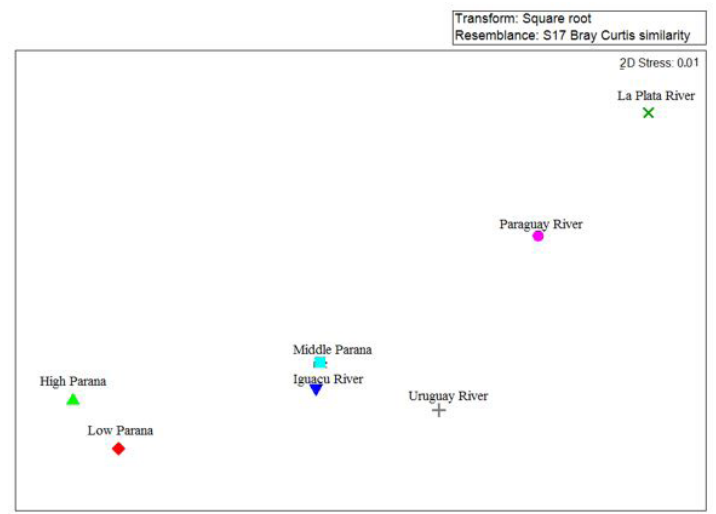

Figure 5. Ordination diagram (NMDS) of the variation in larval density of $L$. fortunei in the main La Plata sub-basins. 
Table 2. Environmental variables, minimum and maximum values, in the La Plata sub-basins during the study period.

\begin{tabular}{|c|c|c|c|c|c|}
\hline Sub-basin & $\begin{array}{l}\text { Total nitrogen } \\
\left(\mu \mathrm{g} . \mathrm{L}^{-1}\right) \\
\text { Min. - Max. }\end{array}$ & $\begin{array}{c}\text { Total } \\
\text { phosphorus } \\
\left(\mu g . L^{-1}\right) \\
\text { Min. - Max. }\end{array}$ & $\begin{array}{l}\text { Chlorophyll } a \\
\left(\mu \mathrm{g} . \mathrm{L}^{-1}\right) \\
\text { Min. - Max. }\end{array}$ & $\begin{array}{c}\text { Transparency } \\
\text { (m) } \\
\text { Min. - Max. }\end{array}$ & $\begin{array}{c}\text { Water } \\
\text { temperature } \\
\left({ }^{\circ} \mathrm{C}\right) \\
\text { Min. - Max. }\end{array}$ \\
\hline Paranaíba River & $141.0-265.6$ & $5.5-15.2$ & $0.54-3.1$ & $3.75-6.0$ & $22.2-28.0$ \\
\hline Grande River & $252.4-403.7$ & $5.4-11.0$ & $0.26-5.76$ & $0.7-5.6$ & $19.4-28.3$ \\
\hline Tietê River & $182.9-7,189.5$ & $9.7-205.4$ & $1.9-31.2$ & $0.75-6.10$ & $19.6-28.6$ \\
\hline Parapanema River & $322.7-655.0$ & $11.2-25.0$ & $0.4-3.7$ & $0.4-2.4$ & $18.3-27.6$ \\
\hline Iguaçu River & $302.3-686.0$ & $11.7-40.8$ & $0.3-3.4$ & $0.4-2.0$ & $14.3-29.3$ \\
\hline High Paraná River & $258.5-866.0$ & $9.9-7.8$ & $0.5-5.1$ & $1.2-8.2$ & $19.2-27.5$ \\
\hline Middle Paraná River & $329.8-513.5$ & $8.9-49.4$ & $0.5-5.9$ & $0.3-2,1$ & $16.2-29.7$ \\
\hline Low Paraná River & $266.8-487.3$ & $36.4-88.1$ & $2.3-5.2$ & $0.4-0.8$ & $14.5-30.1$ \\
\hline La Plata River & $503.7-531.6$ & $39.6-69.1$ & $1.4-8.2$ & $0.6-0.6$ & $13.4-28.5$ \\
\hline Paraguay River & $139.9-818.7$ & $14.7-77.9$ & $1.1-5.7$ & $0.2-1.3$ & $18.7-31.0$ \\
\hline Uruguay River & $286.6-1,455.0$ & $8.1-89.9$ & $0.6-8.19$ & $0.1-2.3$ & $13.1-29.1$ \\
\hline Sub-basin & $\begin{array}{c}\text { pH } \\
\text { Min. - Max. }\end{array}$ & $\begin{array}{c}\text { Electric } \\
\text { conductivity } \\
\left(\mu S^{\prime} \mathrm{cm}^{-1}\right) \\
\text { Min. - Max. }\end{array}$ & $\begin{array}{c}\text { Dissolved } \\
\text { Oxygen }\left(\mathbf{m g . L} \mathbf{L}^{-1}\right) \\
\text { Min. - Max. }\end{array}$ & $\begin{array}{c}\text { Turbidity } \\
\text { (NTU) } \\
\text { Min. - Max. }\end{array}$ & $\begin{array}{c}\text { T.S.S.(mg.L-1) } \\
\text { Min. - Max. }\end{array}$ \\
\hline Paranaíba River & $6.76-7.5$ & $34.5-50.9$ & $4.66-7.63$ & $4.44-15.7$ & $0.9-3.1$ \\
\hline Grande River & $6.53-7.7$ & $26.0-48.6$ & $5.00-9.78$ & $1.75-33.1$ & $0.8-5.7$ \\
\hline Tietê River & $6.37-7.7$ & $116.2-328.0$ & $3.70-9.72$ & $4.43-25.7$ & $1.2-14.8$ \\
\hline Parapanema River & $6.3-7.5$ & $47.2-59.0$ & $6.33-9.08$ & $11.6-52.6$ & $1.6-15.1$ \\
\hline Iguaçu River & $6.2-7.4$ & $39.8-121.0$ & $6.23-9.83$ & $12.3-46.3$ & $1.1-22.5$ \\
\hline High Paraná River & $6.5-7.7$ & $38.1-55.6$ & $5.61-9.79$ & $4.2-23.7$ & $0.5-5.2$ \\
\hline Middle Paraná River & $7.0-7.9$ & $74.2-51.8$ & $5.91-9.61$ & $7.8-50.7$ & $0.7-86.1$ \\
\hline Low Paraná River & $7.0-7.6$ & $92.8-150.3$ & $4.18-9.80$ & $33.8-53.4$ & $24.9-138.0$ \\
\hline La Plata River & $7.9-8.1$ & $66.2-98.1$ & $8.54-10.8$ & $22.4-29.4$ & $6.0-12.8$ \\
\hline Paraguay River & $6.0-7.5$ & $44.0-202.2$ & $2.79-10.1$ & $1.7-82.5$ & $7.5-92.1$ \\
\hline Uruguay River & $6.3-7.8$ & $30.1-121.0$ & $6.32-11.3$ & $6.3-237.2$ & $1.6-116.7$ \\
\hline
\end{tabular}

Table 3. Correlations analyses results ( $\mathrm{r}$ and $\mathrm{p}$ values) between $L$. fortunei larval densities and environmental variables. Significant correlations $(<0.05)$ in bold

\begin{tabular}{lcclcc}
\hline \multicolumn{1}{c}{ Summer data } & $\mathbf{r}$ & $\mathbf{p}$ & Winter data & $\mathbf{r}$ & $\mathbf{p}$ \\
\hline Total nitrogen & -0.2 & 0.2 & Total nitrogen & $\mathbf{- 0 . 5}$ & $\mathbf{0 . 0 0 2}$ \\
Total phosphorus & -0.09 & 0.6 & Total phosphorus & $\mathbf{- 0 . 3}$ & $\mathbf{0 . 0 4}$ \\
Chlorophyll $a$ & 0.02 & 0.8 & Chlorophyll $a$ & -0.3 & 0.07 \\
Water transparency & 0.2 & 0.2 & Water transparency & 0.2 & 0.1 \\
Water temperature & -0.08 & 0.6 & Water temperature & $\mathbf{0 . 4}$ & $\mathbf{0 . 0 1}$ \\
pH & 0.1 & 0.3 & pH & -0.09 & 0.6 \\
Electrical conductivity & -0.2 & 0.1 & Electrical conductivity & -0.1 & 0.4 \\
Dissolved oxygen & $\mathbf{0 . 3}$ & $\mathbf{0 . 0 3}$ & Dissolved oxygen & 0.3 & 0.07 \\
Turbidity & -0.1 & 0.3 & Turbidity & -0.2 & 0.1 \\
T.S.S. & -0.1 & 0.3 & T.S.S. & -0.2 & 0.11 \\
\hline
\end{tabular}

\section{Discussion}

The general distribution of the invasive species L. fortunei in La Plata Basin, indicates a complex scenery. Very high peaks of larvae abundance $\left(>20,000\right.$ ind. $\left.\mathrm{m}^{-3}\right)$ were observed in the three main rivers of the basin (Paraná, Uruguay and Paraguay) and also in the River the La Plata estuary. Maximums around 50,000 to 60,000 ind. $\mathrm{m}^{-3}$ occurred both in the most southern latitude as well as in the north of the basin, 2,000 km apart from each other.

Our data set shows that the variability on larvae abundance in the different basins and sub-basins is enormous, what may reflect the inherent random distribution of plankton organisms in a certain water 
mass. Boltovskoy et al. (2015), for instance, found a huge variability (sample-to-sample-variability) of $L$. fortunei veligers, between 2,000 to 16,000 ind. $\mathrm{m}^{-3}$, in the lower Paraná River delta during an intensive sampling (hourly intervals) along 2 consecutive days. Trend was followed by copepods and cladocerans as well.

Despite the high spatial variability on abundances, temporally the counts were consistently higher during summer, compared to winter. There was only few exceptions, 3 among the 48 distinct sampling sites. This seasonal pattern of variation is well-reported worldwide (Morton, 1977; Morton, 1982), including other regional studies (Cataldo and Boltovskoy, 2000; Darrigran et al., 2007), and population fluctuations were mainly explained by reproductive events.

The La Plata basin exhibits a pronounced climatic complexity, which certainly affect the plankton fauna biological attributes. In case of La Plata River and Uruguay sub-basin sampling sites, were the larvae reduction in winter compared to summer was more pronounced, temperature diminished from $29{ }^{\circ} \mathrm{C}$ in January to $13{ }^{\circ} \mathrm{C}$ in July. In a study on copepods distribution in La Plata basin, (Perbiche-Neves et al., 2015) discriminated distinct groups of species across the north-south gradient in the basin, and the main factor explaining the differential distribution were the winter minimum temperature and to the annual amplitude.

In addition to the seasonal variation in temperature, other environmental variables can influence significantly on L. fortunei larval production, such as dissolved oxygen, calcium, $\mathrm{pH}$, water velocity and suspended solids (Oliveira et al., 2011). Unlike most sampling sites, we found in Salto Caxias reservoir (SCAX U), low Iguaçu River, higher larvae densities $\left(10,430\right.$ ind. $\left.\mathrm{m}^{-3}\right)$ during winter. The considerable decrease in temperature between seasons, 28 to $19^{\circ} \mathrm{C}$, but not dropping to a limiting condition, could be compensated by higher nutritional offer. Winter chlorophyll increased 3.5 times. In La Plata River sampling site, besides the significant fall in temperature (amplitude of $16{ }^{\circ} \mathrm{C}$ between sampling periods), the change in phytoplankton biomass (chlorophyll a), from $8.21 \mu \mathrm{g}$. $\mathrm{L}^{-1}$ in summer to $1.39 \mu \mathrm{g} . \mathrm{L}^{-1}$ in winter, also contributed to the noticeable decrease in the L. fortunei larval abundance (see above).

The analyses between larvae abundance and the limnological variables showed positive significant correlations $(<0.05)$ for oxygen in summer and for temperature in winter. The summer temperatures in the waters of La Plata basin are very high, independent of the latitude (values between $27.5^{\circ} \mathrm{C}$ and $31{ }^{\circ} \mathrm{C}$ in the High Paraná and Paraguay sub-basin, respectively), compromising the oxygen dissolution and negatively affecting the larvae surviving. But for winter, the temperature in the basin is quite variable, mild in the north and cold in south, where the larvae decreases is accentuated.

Very high larval densities during summer occurred in Paraguay River (peak of 52,000 ind. $\mathrm{m}^{-3}$ at S10-RPAG-U). Despite relatively high values of temperature in winter (ca. $24^{\circ} \mathrm{C}$ ) there was a conspicuous decline in densities (mean of 1,119 ind. $\mathrm{m}^{-3}$ ). The Paraguay River drains the Pantanal region, one of the largest wetlands in the world of major ecological importance (Junk et al., 2013). The seasonal larvae diminution could be related to effects of the regional natural phenomenon known as "decoada", which is associated with the decomposition of organic matter (mostly aquatic macrophytes), after the flood period (February/March). Acidification and anoxia is expected. Sharp drop of dissolved oxygen concentration, from 7.0 to $0.3 \mathrm{mg} \mathrm{L}^{-1}$, remaining that low for two months could be observed (Andrade et al., 2014). This condition is much lower than the inferior limit tolerated by the species (Ricciardi, 1998).

For winter data there was also significant negative correlation of total phosphorus and total nitrogen with larvae abundance. These results indicate, indirectly, that higher trophic conditions may inhibit L. fortunei reproduction. Boltovskoy et al. (2015) attributed the interruption of reproduction of the species in Salto Grande reservoir (Argentine/Uruguay) during dry summers (low water flow condition) to the intensive growth of Microcystis, a well-known cyanobacteria genus that can produces toxic substances.

Among the sampled environments, the most compromised one in terms of water quality is the Tietê River, which receives the discharges of São Paulo metropolitan region. Pareschi et al. (2008) were the first to described L. fortunei in Tietê River. In our study the larvae abundances were very low (maximum of 176 ind. $\mathrm{m}^{-3}$ in summer) in the first sampling site selected in this river, Barra Bonita $(\mathrm{BBON})$ reservoir. In the second selected site, Três Irmãos reservoir (TIRM) near to the river mouth and hundreds of $\mathrm{km}$ far from major pollution sources, the abundance reached 3,420 ind. $\mathrm{m}^{-3}$ in summer, but decreased to 801 ind. $\mathrm{m}^{-3}$ in winter. According to Ernandes-Silva et al. (2016) high values of chlorophyll concentration provides food resources to L. fortunei. The maximum value of chlorophyll concentration $\left(31.2 \mu \mathrm{g} \mathrm{L}^{-1}\right)$ was observed in this sub-basin, but we did not found a large number of individuals. Probably this related to the poor quality of the local phytoplankton as a nutritional resource.

The abundance of L. fortunei was also limited in the low Paraná River, despite its proximity to the River the La Plata estuary were the species was initially introduced and where populations are very dense. Besides the poor water quality (e.g. high phosphorus concentration and low water transparency) observed in this river stretch, the prevalence of high water velocity (riverine condition) could also inhibit the development of dense populations. Hydrological stress as limiting factors of the L. fortunei invasion was proposed by (Campos et al., 2012), based on observations in the upper Paraná River sub-basin.

Contrasting to the lower river course in the upper Paraná River there is a high concentration of reservoirs, particularly in Brazil. Reservoirs comprise an integrated and complex system of relatively clean electricity generation, based on a renewable energy source. However, it causes deep socio-environmental changes and interferes in the structure 
and ecological functioning of the river basins (Tundisi and Matsumura-Tundisi, 2003; Nogueira et al., 2006; Agostinho et al., 2007; Nogueira et al., 2012). The first registers of golden mussel in the reservoir cascades of this region of La Plata were reported in the beginning of 2000's. Between 2001 and 2004 its presence was detected in the reservoirs of Ilha Solteira, Jupiá, Porto Primavera and Itaipu, upper Paraná River (Zanella and Marenda, 2002; Mansur et al., 2004; Von Ruckert et al., 2004 and Avelar et al., 2004); during 2006 in the reservoirs of Canoas I, Canoas II and Capivara, Paranapanema River (Garcia et al., 2009; Rocha et al., 2011); during 2007/2008 in Tibagi and Iguaçu Rivers (Pestana et al., 2010); during 2004 in the Tietê River (already mentioned) (Pareschi et al., 2008). In the most northern large rivers of the basin, Paranaíba and Grande Rivers, we did not register the species presence. But very low densities of larvae had already been previously (2006) observed in these rivers lower stretches (Campos et al., 2012).

In the Uruguay River, whose mouth is not far from La Plata River estuary, the first golden mussel record date from 2001 (Brugnoli et al., 2005). According to the authors, until 2003 the species distribution was limited by Salto Grande hydropower dam. After that, the species experienced a new expansion phase and dispersed further north. The success in the colonization process was attributed to the availability of hard substrate in the shores and river bottom.

Our results collected in summer 2010 show a high abundance of $L$. fortunei larval stages in the Uruguay River lower stretch (RURU-L) and Salto Grande Reservoir (SGRA-D). Abundances reached 22,253 and 47,976 ind. $\mathrm{m}^{-3}$, respectively. At that occasion, the density in the river middle section (RURU-M2) was only 1.0 ind. $\mathrm{m}^{-3}$. Nevertheless, in our 2014 summer campaign, the species had already moved several hundred kilometers upstream, with density of 4.246 ind. $\mathrm{m}^{-3}$ in the Brazilian territory (S14 RURU-IRA).

Interior routes of commercial navigation transporting six millions tons of cargo per year (Silveira, 2005; Oliveira et al., 2004; Oliveira et al., 2011) explain the fast dispersion of L. fortunei along the Paraguay River. The species was found in 1998, near the city of Corumbá (Brazil) (Oliveira et al., 2006), more than 2,000 km far from the introduction area (La Plata estuary).

According to (Darrigran, 2002) the dispersion rate of golden mussel in the lower and middle stretches of the Paraná River (Argentina) was very fast, $240 \mathrm{~km}$ year ${ }^{-1}$. In this region, the river is characterized by the absence of dams and intense navigation activity, which favor dispersion through incrustation of adult and juvenile forms in boats.

The invasive species L. fortunei is presently widely distributed in the La Plata basin, reaching high larval densities, superior to 10,000 ind. $\mathrm{m}^{-3}$, in all major sub-basins. In only two decades the species, introduced in the extreme south region of the basin (La Plata River estuary), reached lower latitudes in the upper Paraná River sub-basin - in a counter-flux displacement of at least 2,000 km (10 latitude degrees). The trend of higher larvae abundances in summer is corroborated, with a few exceptions. The winter temperature, associated to decrease in food availability, greatly influence the size of the population in the La Plata basin higher latitudes, but do not limit the species permanence.

Higher values of larvae occurred in the La Plata River, followed by Paraguay, while lower larvae abundance was associated with the Paraná River (see NMDS graphic results). Nevertheless, our first hypothesis was refuted. It was not observed a decreasing south-north gradient in larval densities, which could be expected if a gradual and progressive spatial dispersion and colonization had occurred. Hydrological forces and regional climate, influencing on the limnological characteristics, should be responsible for not have been observed a clear latitudinal pattern.

In general, the second hypothesis was also not completely satisfied. We did not observed a significant increase in density associated with more lentic conditions (reservoirs). Even so, important exceptions (e.g. Yacyretá) must be considered.

Growing expansion towards north, northwest and northeast regions of the continent tend to continue. Recently, the introduction of L. fortunei was reported for another large basin in South America, São Francisco River, Southeast Brazil (Barbosa et al., 2016).

\section{Acknowledgements}

We are grateful to Danilo Naliato, Gilmar Perbiche-Neves, José Roberto Debastiani Júnior, Silvia Maria Casanova and Jorge Laço Portinho, for their help in the field work expeditions. To Danilo Naliato also for the sampling points map. To Fapesp (proc. 2009/00014-6) and OEA (contract 253015) for financial support.

\section{References}

AGOSTINHO, A.A., GOMES, L.C. and PELICICE, F.M., 2007. Ecologia e manejo de recursos pesqueiros em reservatórios do Brasil. Maringá: Eduem. 501 p.

AMERICAN PUBLIC HEALTH ASSOCIATION - APHA, 2005. Standard methods for the examination of water and wastewater. 21th ed. Washington, DC: APHA.

ANDRADE, M.H.S., BRANDIMARTE, A.L., CALHEIROS, D.F. and TAMBOSI, L., 2014. Spatial and limnological caracterization of the Paraguai river floodplain area, Southern Pantanal, with emphasis on the 'decoada' phenomenon. Anais $5^{\circ}$ Simpósio de Geotecnologias no Pantanal, 22-26 de novembro 2014, Campo Grande, MS. Campinas: Embrapa Informática Agropecuária/ INPE, pp. 220-230.

AVELAR, W.E.P., MARTIM, S.L. and VIANNA, M.P., 2004. A new occurrence of Limnoperna fortunei (Dunker 1856) (Bivalvia, Mytilidae) in the State of São Paulo, Brazil. Brazilian Journal of Biology = Revista Brasileira de Biologia, vol. 64, no. 4, pp. 739-742. PMid:15744413. http://dx.doi.org/10.1590/S151969842004000500002.

BARBOSA, N.P.U., SILVA, F.A., OLIVEIRA, M.D., SANTOS NETO, M.A., CARVALHO, M.D. and CARDOSO, A.V., 2016. Limnoperna fortunei (Dunker, 1857) (Mollusca, Bivalvia, 
Mytilidae): first record in the São Francisco basin, Brazil. Check List, vol. 12, no. 1, pp. 1846. http://dx.doi.org/10.15560/12.1.1846.

BAZÁN, J.M. and ARRAGA, E., 1993. O Rio de La Plata, um sistema fluvio-marítima Frágil? Acercamiento a una definición de la calidad de sus aguas. In: A. BOLTOVSKOY and H. LOPEZ, eds. Conferencias de Limnología. La Plata: Instituto de Limnología Dr. R. Ringuelet, pp. 71-82.

BOLTOVSKOY, D., MORTON, B., CORREA, N., CATALDO, D., DAMBOENEA, C., PENCHASZADEH, P.E. and SYLVESTER, F., 2015. Reproductive output and seasonality of Limnoperna fortunei. In: Limnoperna fortunei: the ecology, distribution and control of a swiftly spreading invasive fouling mussel. Berlin: Springer, pp. 77-103.

BOON, P.J., DAVIES, B.R. and PETTS, G.E., 2000. Global perspectives on river conservation: science, policy and practice. Chichester: Wiley. 548 p.

BRUGNOLI,E., CLEMENTE, J., BOCCARDI,L., BORTHAGARAY, A. and SCARABINO, F., 2005. Golden mussel Limnoperna fotrtunei (Bivalia: Mytilidae) distribution in the main hydrographical basins of Uruguay: update and predictions. Anais da Academia Brasileira de Ciencias, vol. 77, no. 2, pp. 235-244. PMid:15895160. http:// dx.doi.org/10.1590/S0001-37652005000200004.

BRUGNOLI, E., DABEZIES, M.J., CLEMENTE, J.M. and MUNIZ, P., 2011. Limnoperna fortunei (Dunker 1857) en el sistema de embalses del Rio Negro, Uruguay. Oecologia Australis, vol. 15, no. 3, pp. 576-592. http://dx.doi.org/10.4257/oeco.2011.1503.10.

CAMPOS, M.C.S., LANZER, R. and CASTRO, P.T., 2012. Hydrological stress as a limiting factor of the invasion of Limnoperna fortunei (Dunker, 1857) in the Upper Paraná River (Brazil). Acta Limnologica Brasiliensia, vol. 24, no. 1, pp. 64-82. http://dx.doi. org/10.1590/S2179-975X2012005000027.

CARLTON, J.T., 1985. Transoceanic and interoceanic dispersal of coastal marine organisms: the biology of ballast water. Oceanography and Marine Biology, vol. 23, pp. 313-371.

CATALDO, D.H. and BOLTOVSKOY, D., 2000. Yearly reproductive activity of Limnoperna fortunei (Bivalvia) as inferred from the occurrence of its larvae in the plankton of the lower Parana river and the Rio de La Plata estuary (Argentina). Aquatic Ecology, vol. 34, no. 3, pp. 307-317. http://dx.doi.org/10.1023/A:1009983920942.

DAMBORENEA, M.C., 1999. The reproductive cycle of Limnoperna fortunei (Dunker, 1857) (Mytilidae) from a neotropical temperate locality. Journal of Shellfish Research, vol. 18, pp. 361.

DARRIGRAN, G. and PASTORINO, G., 1995. The recent introduction of a freshwater asiatic bivalve, Limnoperna fortunei (Mytilidae) into South America. The Veliger, vol. 38, no. 2, pp. 171-175.

DARRIGRAN, G., 2002. Potential impact of filter-feeding invaders on temperate inland freshwater environments. Biological Invasions, vol. 4, no. 1, pp. 145-156. http://dx.doi. org/10.1023/A:1020521811416.

DARRIGRAN, G., DAMBORENEA, C. and GRECO, N., 2007. An evaluation pattern for antimacrofouling procedures: Limnoperna fortunei Larvae study in a hydroelectric power plant in South America. Ambio, vol. 36, no. 7, pp. 575-579. PMid:18074895. http:// dx.doi.org/10.1579/0044-7447(2007)36[575:AEPFAP]2.0.CO;2.

DARRIGRAN, G.A. and DAMBORENEA, C., 2011. Ecosystem engineering impact of Limnoperna fortunei in South America. Zoological Science, vol. 28, no. 1, pp. 1-7. PMid:21186940. http:// dx.doi.org/10.2108/zsj.28.1.
EILERS, V., OLIVEIRA, M.D. and ROCHE, K.F., 2011. Density and body size of the larval stages of the invasive Golden mussel (Limnoperna fortunei) in two neotropical rivers. Acta Limnologica Brasiliensia, vol. 23, no. 3, pp. 282-292. http://dx.doi.org/10.1590/ S2179-975X2012005000006.

ERNANDES-SILVA, J., RAGONHA, F.H., JATI, S. and TAKEDA, A.M., 2016. Limnoperna fortunei Dunker, 1857 larvae in different environments of a Neotropical floodplain: relationships of abiotic variables and phytoplankton with different stages of development. Brazilian Journal of Biology $=$ Revista Brasileira de Biologia, vol. 76, no. 1, pp. 154-161. PMid:26871750. http://dx.doi. org/10.1590/1519-6984.15514.

GARCIA, D.A.Z., ORSI, M.L., CASIMIRO, A.C.R. and KURCHEVSKI, G., 2009. Registros de ocorrência de Limnoperna fortunei no médio e baixo Paranapanema: uma ameaça às suas águas. In: Anais do IX Congresso de Ecologia do Brasil, 13-17 de Setembro de 2009, São Lourenço, Brasil.

GOLTERMAN, H.L., CLYMO, R.S. and OHSTAD, M.A., 1978. Methods for physical; chemical analysis of fresh waters. 2nd ed. Oxford: Blackweel Scientific Publications.

JUNK, W.J., PIEDADE, M.T.F., LOURIVAL, R., WITTMANN, F., KANDUS, P., LACERDA, L.D., BOZELLI, R.L., ESTEVES, F.A., CUNHA, N., MALTCHIK, L. and SCHOENGART, J., 2013. Brazilian wetlands: definition, delineation and classification for research, sustainable management and protection. Aquatic Conservation: Marine and Freshwater Environments, vol. 24, no. 1, pp. 5-22. http://dx.doi.org/10.1002/aqc.2386.

LOCKWOOD, J., HOOPES, M. and MARCHETTI, M., 2007. Invasion ecology. Oxford: Blackwell.

MACKRETH, F.J.H., HERON, J. and TALLING, F.J., 1978. Water analysis: some revised methods for limnologists. Ambleside: Freshwater Biological Association, 120 p. (Scientific Publication, 36).

MAGARA, Y., MATSUI, Y., GOTO, Y. and YUASA, A., 2001. Invasion of the non-indigenous nuisance mussel, Limnoperna fortunei, into water supply facilities in Japan. Journal of Water Supply, Research and Technology, vol. 50, no. 3, pp. 113-124.

MANSUR, M.C.D., QUEVEDO, C.B., SANTOS, C.P. and CALLIL, C.T., 2004. Prováveis vias de introdução de Limnoperna fortunei (Dunker, 1857) (Mollusca, Bivalvia, Mytilidae) na Bacia da Laguna dos Patos, Rio Grande do Sul e novos registros de invasão no Brasil pelas bacias do Paraná e Paraguai. In: J.S.V. SILVA and R.C.C.L. SOUZA, eds. Água de lastro e bioinvasão. Rio de Janeiro: Interciencia, pp. 33-38.

MORTON, B.S., 1977. The population dynamics of Limnoperna fortunei (Dunker, 1857) (Bivalvia: Mytilidae) in Plove Cover reservoir, Hong Kong. Malacologia, vol. 16, no. 1, pp. 165-182.

MORTON, B.S., 1982. The reproductive cycle of Limnoperna fortunei (Dunker, 1857) (Bivalvia: Mytilidae) fouling Hong Kong' raw water supply systems. Oceanologia et Limnologia Sinica, vol. 13 , no. 4 , pp. 312-324.

MORTON, B.S., 1987. Comparative life history tactics and sexual strategies of the fresh and brackish water bivalve fauna of Hong Kong and Southern China. American Malacological Bulletin

MUGNI, H., MAINE, A. and BONETTO, C., 2005. Phosphate and nitrogen transformation in a large floodplain river. In: L. SERRANO and H. GOLTERMAN, eds. Phosphate in Sediments. Leiden: Backhuys Publishers, pp. 139-149.

NOGUEIRA, M.G., JORCIN, A., VIANNA, N.C. and BRITTO, Y.C., 2006. Reservatórios em cascata e os efeitos na limnologia e 
organização das comunidades bióticas (fitoplâncton, zooplâncton e zoobentos): um estudo de caso no rio Paranapanema (SP/PR). In: M.G. NOGUEIRA, R. HENRY and A. JORCIN, eds. Ecologia de reservatórios: impactos potenciais, ações de manejo e sistemas em cascata. 2. ed. São Carlos: Rima, pp. 435-459.

NOGUEIRA, M.G., PERBICHE-NEVES, G. and NALIATO, D.A.O., 2012. Limnology of two contrasting Hydroelectric Reservoirs (Storage and Run-of-River) in Southeast Brazil. In: H.S. BOROUGENI, org. Hydropower: practice and application. Rijeka: INTECH, pp. 167-184.

OLIVEIRA, M.D., CALHEIROS, D.F., JACOBI, C.M. and HAMILTON, S.K., 2011. Abiotic factors controlling the establishment and abundance of the invasive golden mussel Limnoperna fortunei. Biological Invasions, vol. 13, no. 3, pp. 717-729. http://dx.doi. org/10.1007/s10530-010-9862-0.

OLIVEIRA, M.D., PELLEGRIN, L.A., BARRETO, R.R., SANTOS, C.L. and XAVIER, I.G., 2004. Área de Ocorrência do Mexilhão Dourado (Limnoperna fortunei) na Bacia do Alto Paraguai, entre os anos de 1998 e 2004. Corumbá: Embrapa Pantanal. 19 p.

OLIVEIRA, M.D., TAKEDA, A.M., BARROS, L.F., BARBOSA, D.S. and RESENDE, E.K., 2006. Invasion by Limnoperna fortunei (Dunker, 1857) (Bivalvia, Mytilidae) of the Pantanal wetland, Brazil. Biological Invasions, vol. 8, no. 1, pp. 97-104. http:// dx.doi.org/10.1007/s10530-005-0331-0.

PARESCHI, D.C., MATSUMURA-TUNDISI, T., MEDEIROS, G.R., LUZIA, A.P. and TUNDISI, J.G., 2008. First occurrence of Limnoperna fortunei (Dunker, 1857) in the Rio Tietê watershed (São Paulo State, Brazil). Brazilian Journal of Biology = Revista Brasileira de Biologia, vol. 68, no. 4, (suppl.), pp. 1107-1114. PMid:19197480. http://dx.doi.org/10.1590/S151969842008000500017.

PASTORINO, G., DARRIGRAN, G., MARTIN, S. and LUNASCHI, L., 1993. Limnoperna fortunei (Dunker, 1857) (Mytilidae), Nuevo bivalvo invasor em águas del Río de la Plata. Neotrópica, vol. 39, no. 101-102, pp. 34.

PERBICHE-NEVES, G., BOXSHALL, G.A., PREVIATTELLI, D., NALIATO, D.A.O., PIE, M.R., ROCHA, C.E.F. and NOGUEIRA, M.G., 2015. Regulation of the abundance and turnover of copepod species by temperature, turbidity and habitat type in a large river basin. Austral Ecology, vol. 40, no. 6, pp. 718-725. http://dx.doi. org/10.1111/aec.12240.

PESTANA, D., OSTRENSKY, A., TSCHÁ, M.K. and BOEGER, W.A., 2010. Prospecção do molusco invasor Limnoperna fortunei (Dunker, 1857) nos principais corpos hídricos do estado do Paraná, Brasil. Papéis Avulsos de Zoologia, vol. 50, no. 34, pp. 553-559. http://dx.doi.org/10.1590/S0031-10492010003400001.

PIZARRO, M.J., HAMMERLY, J., MAINE, M.A. and SUÑE, N., 1992. Phosphate adsorption on bottom sediments of the Rio de La Plata. Hydrobiologia, vol. 228, no. 1, pp. 43-54. http:// dx.doi.org/10.1007/BF00006475.

RICCIARDI, A., 1998. Global range expansion of the Asian mussel Limnoperna fortunei (Mytilidae): Another fouling threat to freshwater systems. Biofouling, vol. 13, no. 2, pp. 97-100. http:// dx.doi.org/10.1080/08927019809378374.

ROCHA, O., ESPÍNDOLA, E.L.G., RIETZLER, A.C., FENERICHVERANI, N. and VERANI, J.R., 2011. Animal Invaders in São Paulo State Reservoirs. Oecologia Australis, vol. 15, no. 3, pp. 631-642. http://dx.doi.org/10.4257/oeco.2011.1503.14.

ROJAS, M., JOSÉ DE PAGGI, S. and PAGGI, J., 2015. Impacts of Limnoperna fortunei on Zooplankton. In: D. BOLTOVSKOY, ed. The Ecology, distribution and control of a Swiftly Spreading invasive fouling mussel. Switzerland: Springer, pp. 177-190. Invading Nature - Springer Series in Invasion Ecology, no. 10.

SANTOS, C.P., WÜRDIG, N.L. and MANSUR, M.C.D., 2005. Fases larvais do mexilhão dourado Limnoperna fortunei (Dunker) (Mollusca, Bivalvia, Mytilidae) na Bacia do Guaíba, Rio Grande do Sul, Brasil. Revista Brasileira de Zoologia, vol. 22, no. 3, pp. 702-708. http://dx.doi.org/10.1590/S0101-81752005000300029.

SILVEIRA, J.P., 2005 [viewed 25 January 2016]. Amcham Brasil. http://www.amcham.com.br/advocacy/informativos/ advocacy2001-1210f_arquivo.

STRICKLAND, J. D., PARSONS, T. R., 1960. A manual of sea water analysis. Nanaimo: Pacific Oceanographic Group. Fhisheries Research Board of Canada, no. 125.

TUNDISI, J.G. and MATSUMURA-TUNDISI, T., 2003. Integration of research and management in optimizing multiple uses of reservoirs: the experience in South America and Brazilian case studies. Hydrobiologia, vol. 500, no. 1-3, pp. 231-242. http:// dx.doi.org/10.1023/A:1024617102056.

TUNDISI, J.G., 1994. Tropical South America: present and perspectives. In: R. MARGALEF, ed. Limnology now: a paradigm of planetary problems. Amsterdan: Elsevier Science B, pp. 353-424.

VALDERAMA, J.G., 1981. The simultaneous analysis of total nitrogen and phosphorus in natural waters. Marine Chemistry, vol. 10, no. 2, pp. 109-122. http://dx.doi.org/10.1016/03044203(81)90027-X

VON RUCKERT, G., CAMPOS, M.C.S. and ROLLA, M.E., 2004. Alimentação de Limnoperna fortunei (Dunker 1857): taxas de filtração com ênfase ao uso de Cyanobacteria. Acta Scientiarum. Biological Sciences, vol. 26, no. 4, pp. 421-429.

ZANELLA, O. and MARENDA, L.D., 2002. Ocorrência de Limnoperna fortunei na Central Hidrelética de Itaipu. In: Anais do $5^{\circ}$ Congresso Latinoamericano de Malacologia. São Paulo: Instituto de Biociências. 41 p. 